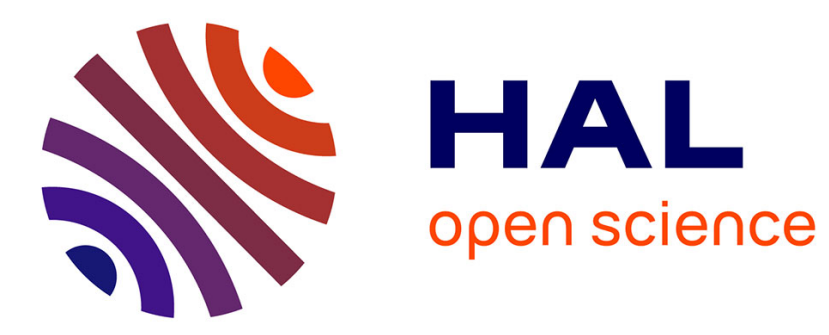

\title{
Bioencapsulation of microbial inoculants for better soil-plant fertilization. A review
}

Mauricio Schoebitz, Maria López, Antonio Roldán

\section{To cite this version:}

Mauricio Schoebitz, Maria López, Antonio Roldán. Bioencapsulation of microbial inoculants for better soil-plant fertilization. A review. Agronomy for Sustainable Development, 2013, 33 (4), pp.751-765. 10.1007/s13593-013-0142-0 . hal-01201392

\section{HAL Id: hal-01201392 \\ https://hal.science/hal-01201392}

Submitted on 17 Sep 2015

HAL is a multi-disciplinary open access archive for the deposit and dissemination of scientific research documents, whether they are published or not. The documents may come from teaching and research institutions in France or abroad, or from public or private research centers.
L'archive ouverte pluridisciplinaire HAL, est destinée au dépôt et à la diffusion de documents scientifiques de niveau recherche, publiés ou non, émanant des établissements d'enseignement et de recherche français ou étrangers, des laboratoires publics ou privés. 


\title{
Bioencapsulation of microbial inoculants for better soil-plant fertilization. A review
}

\author{
Mauricio Schoebitz • Maria D. López • Antonio Roldán
}

Accepted: 4 March 2013 / Published online: 27 March 2013

(C) INRA and Springer-Verlag France 2013

\begin{abstract}
Plant fertilization is a major issue in the context of increasing population and food risk, higher cost of fertilizers, and low target efficiency of traditional mineral fertilization practices. Alternatively, application of microbial inoculants to the soil can enhance the uptake of nutrients by plants and increase the efficiency of mineral fertilizers and manures. Encapsulation methods involve covering and protecting the microorganisms. Encapsulation of bacterial cells has been challenged and used mainly in the agricultural industry using processes, such as spray drying, interfacial polymerization, or cross-linking. Here, we review techniques for microbial inoculants and their benefits for sustainable agriculture. Techniques include fluidized bed, extrusion, molecular inclusion, coacervation, liposomes, ionic or inverse gelation, and oil-entrapped emulsion. Major topics discussed are formulation of microbial inoculants, conventional inoculants, bioencapsulation materials, bioencapsulation techniques, and future trends. We found that (1) conventional inoculant does not provide adequate protection for microorganisms. (2) Bioencapsulation improves the protection and controlled release of bacteria. (3) Sodium alginate is one of the most used products for the bioencapsulation of microorganisms. (4) The bioencapsulation of microbial inoculants is performed with the incorporation of an active ingredient into a matrix followed by a mechanical operation, and finally stabilization by a chemical or physical-chemical process. (5) Spray-drying
\end{abstract}

M. Schoebitz $(\bowtie) \cdot$ A. Roldán

Department of Soil and Water Conservation, CSIC-Centro de

Edafología y Biología Aplicada del Segura, P.O. Box 164,

Campus de Espinardo, 30100, Murcia, Spain

e-mail: mschoebitz@gmail.com

\section{D. López}

Instituto Murciano de Investigación y Desarrollo Agrario y

Alimentario (IMIDA), c/Mayor s/n, 30150,

La Alberca, Murcia, Spain process works on a continuous basis, low operating cost, and high quality of capsules in good yield, although the high temperature used in the process is not very appropriate for encapsulating non-spore-forming bacteria. 6) Fluid-bed process is a promising encapsulation technique for large-scale production in agricultural industry. (7) Ionic gelation is currently the most adequate method found to encapsulate bacteria. (8) Some advantages and drawbacks are found for each technique; therefore, the selection of suitable bioencapsulation method will depend on bacteria strain, cost, processing conditions, and handling.

Keywords Immobilization · Microencapsulation · Spray drying - Cross-linking - Coacervation - Carrier material . Shelf-life $\cdot$ PGPR/PGPB

Contents

1. Introduction

2. Formulation of microbial inoculants

3. Conventional inoculants

4. Bioencapsulation

4.1 Bioencapsulation materials

4.2 Survival of rhizobacteria encapsulated in alginate

4.3 Starch filler in alginate beads

5. Bioencapsulation techniques

5.1 Physical processes

5.1.1 Spray drying

5.1.2 Fluidized bed

5.1.3 Extrusion

5.2 Chemical processes

5.2.1 Molecular inclusion

5.2.2 Interfacial polymerization

5.3 Physicochemical processes

5.3.1 Coacervation

5.3.2 Liposomes 


\subsubsection{Ionic gelation}

5.3.4 Inverse gelation microcapsules by using alginate

5.3.5 Beads by oil-entrapped emulsion

6 Conclusions and future trends

\section{Introduction}

Immobilization and encapsulation of bacterial cells has been widely used in agriculture, pharmaceutical, food, and other industries to achieve a protective structure or a capsule allowing immobilization, protection, release, and functionalization of active ingredients. Therefore, less exposed to adverse environmental factors thanks to encapsulation, tends to stabilize cells, potentially enhancing their viability and stability in the production, storage, and handling of cultures and also confers additional protection during rehydration (Kim et al. 1996).

Rhizobacteria are free-living bacteria isolated from agricultural lands and crop plants, including traditional isolations from cereals and grasses (Bashan and de-Bashan 2005; Park et al. 2005; Lugtenberg and Kamilova 2009; Schoebitz et al. 2009). They are often labeled as plant growth-promoting rhizobacteria (PGPR), which colonize the surface of the root or intercellular spaces of the host plant, frequently improving root establishment. In this regard, PGPR have a potential role in developing sustainable agriculture for crop production (Bashan et al. 2004; Rivera-Cruz et al. 2008). These mechanisms lead to plant growth promotion of diverse nature such as nonsymbiotic nitrogen fixation (Pedraza 2008), phosphate solubilization (Rodriguez et al. 2006; Zaidi et al. 2009), and production of various phytohormones improving root growth, water absorption, and nutrients (Dobbelaere et al. 2001; Spaepen et al. 2007). Nevertheless, colonization of plant roots by direct inoculation of free PGPR cells into the soil is not easy because it is susceptible to environmental variations, such as soil conditions, fluctuation of $\mathrm{pH}$ and temperature, humidity, protozoa predation, and salt stress $(\mathrm{Wu}$ et al. 2012). This unpredictability of the PGPR inoculation success on plants is mainly due to quality of formulations of inoculants containing an effective bacterial strain and determines the success or failure of a biological agent. Cell survival can be improved by immobilizing them into biodegradable carriers (Fig. 1), being formulation the industrial art of converting a promising PGPR strain in a commercial inoculant product (Bashan 1998). Peat and clay inoculants present a high chemical variability and low cells survival on storage conditions (Cassidy et al. 1996). Therefore, improving the cell survival during storage period to ensure good protection of microbial inoculants in soil is a major goal to obtain a positive response on plant inoculation (Vassilev et al. 2001). Inoculation

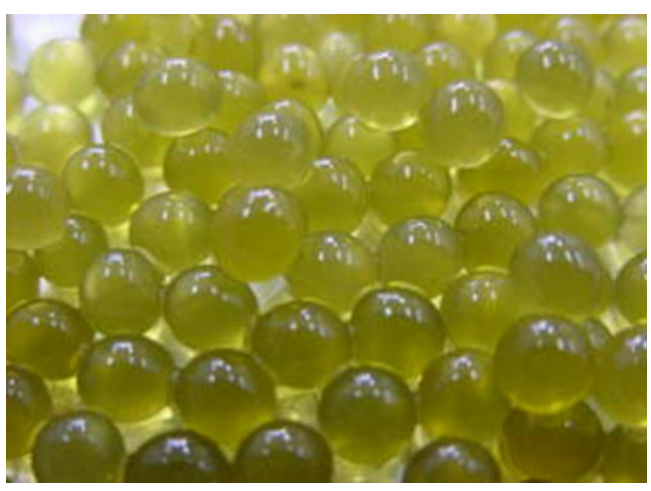

Fig. 1 Immobilization of microbial cells in calcium alginate beads by cross-linking technique

strategies include application of formulations aimed at providing a protective niche together with the provision of nutrients sources (Rekha et al. 2007) and appropriate conditions for transport, handling, and storage (Bashan et al. 2002).

Commercial inoculants were first introduced in 1896 using cultures of Rhizobium, which were grown in flat glass bottles containing only a small amount of gelatin medium (Smith 1992). Other early inoculants carriers and formulations utilized were liquids, sterilized soil, and rhizobia dried on cotton (Smith 1997). In 1897, Bayer released on the German market a product made of bacteria grain which was based on the species Bacillus subtilis. In $1958,10^{7}$ ha were inoculated using two species, Azotobacter chroococcum and Bacillus megaterium var phosphaticum in the Soviet Union (Lemanceau 1992).

Recently, the yield generated by microbial inoculants has increased from 50 to $70 \%$ of the total area tested finding over 2 million ha of the species B. subtilis applied in the USA. Despite these results, the soil inoculation continues to be an experimental field in various countries with different plants and soil conditions (Lemanceau 1992). The outcomes achieved on inoculation of PGPR in different regions of the world under different crop types and soil conditions evidenced a significant increase in crop yields (Okon and Labandera-Gonzalez 1994; Fuentes-Ramirez and CaballeroMellado 2005; Diaz-Zorita and Fernandez-Canigia 2009)

\section{Formulation of microbial inoculants}

Inoculants carriers have been used to improve effectiveness by supplying nutrients, protection from desiccation, and slow cells release. PGPR works optimally under laboratory and greenhouse conditions. However, formulating microorganisms into a product and applying is really difficult under field conditions (Stephens and Rask, 2000). The success of using microbial inoculants introduced into soil requires the 
survival of an adequate numbers of bacteria reaching suitable habitats where they can thrive (Heijnen and Van Veen 1991). For these reasons, formulation is a key factor in the success of microbial inoculants.

The carrier is usually a convenient and economical material, which is able to release slowly viable cells in highquality physiological condition, containing one or more beneficial bacteria (Bashan 1998). There are a number of alternative carriers and formulations for delivery of bacteria: talc (Kloepper and Schroth 1981), vermiculite, perlite (Temprano et al. 2002), polyacrylamide (Dommergues et al. 1979), carrageenan (Cassidy et al. 1996), alginate (Bashan 1986), alginate-starch (Schoebitz et al. 2012), alginate-humic acid (Young et al. 2006), and powder formulations (Amiet-Charpentier et al. 1999; Denton et al. 2009), although the most practical carriers used worldwide on commercial crops are peats (Rose et al. 2011), liquids (Albareda et al. 2008; Diaz-Zorita and Fernandez-Canigia 2009), and clays (Goss et al. 2003).

\section{Conventional inoculants}

Peats are the most commonly used carriers to inoculate seed legumes with rhizobia (Denton et al. 2009). Peat is a complex organic material with a high variability. This particular situation affects on the quality of the final product, stability during storage, and survival of microorganisms in the final product since microbiological contamination decreases the shelf life of the inoculants (Bashan 1998). Furthermore, peat formulations are not able to ensure high cells density and after 6 months of storage a reduction on cells viability is observed (Fallik and Okon 1996).

Liquid formulations are inoculants, which use broth cultures mainly in water, but also in mineral or organic oils. The seeds are either dipped into the inoculant before sowing, or an applicator evenly sprays the liquid inoculant on the seeds (Bashan, 1998). Liquid formulations simplify production and application for the farmers and may have some advantages since they use low-cost material and are easily attainable by small producers (Singleton et al. 2002; Albareda et al. 2008). Liquid inoculants allow contacting directly seeds and microorganisms and consequently increasing the survival of bacteria on plant roots. However, bacterial survival rates on liquid formulations decrease because this technique does not provide a protective environment for microorganisms and the number of bacteria distributed in each seed is quite heterogeneous. In addition, microorganisms are not sufficiently protected against environmental conditions and contamination during storage, transport, and application into the soil (Bashan et al. 2002). The use of liquid inoculants mainly requires a correct storage, without losing their efficiency and cell viability. A stable population of rhizobia on liquid formulations can be stored for 3 months (Albareda et al. 2008); whereas, PGPR on liquid formulation could show a decrease on the number of living cells (Bashan et al. 2002; Haggag and Singer 2012).

Clays are widely used as microbial inoculants and have a long history of usage in various agricultural formulations applied as granules, suspensions, and powder. Clays can act as a desiccant providing excellent storage for dried inoculants due to large surface area, pore size distribution, and total porosity. Besides, water can be controlled to provide moisture for biologically active formulations (Goss et al. 2003). In addition, clays absorb or distribute dispersing and suspending agents. Clays inoculants carriers increased survival levels of rhizobia in soil for 60 days, being these beneficial effects recorded the result of the creation of protective microhabitats accessible to the bacteria but inaccessible to predators (Heijnen and Van Veen 1991; Heijnen et al. 1992).

\section{Bioencapsulation}

The principle of rhizobacteria bioencapsulation is to protect the microorganisms introduced into the soil and to ensure a gradual and prolonged release (Bashan 1986; Kim et al. 2012). The degradation rate of the encapsulation matrix will have a direct relation with the biological activity of the soil microorganisms. The dried capsules can be stored at room temperature for a long period presenting a favorable environment for bacteria and reducing the risk of decreased survival. These inoculants can be improved by incorporating essential nutrients for bacterial growth, transforming the capsules in bioreactors, which are capable of increasing the number of encapsulated bacteria inoculated into the soil. Bacterial inoculants have solved many problems associated with traditional peat inoculants, which originate great variability in peat quality (Deaker et al. 2004). Numerous advantages related to the bioencapsulation of rhizobacteria are found, for instance, controlled release of bacteria into the soil, protection of microorganisms in the soil against biotic and abiotic stresses, and contamination reduction during storage and transport.

\subsection{Bioencapsulation materials}

Natural and synthetic polymers have been used in the bioencapsulation of rhizobacteria. Hydrogels extracted from seaweed, such as alginate, carrageenan, agar-agar, and agarose, considered as natural, are formed by polymerization or cross-linking (Table 1). Also, certain synthetic polymers have been used for bioencapsulation of living cells, such as polyacrylamides, polystyrene, and polyurethane (Trevors et al. 1992; Cassidy et al. 1996). Gums and proteins are 
Table 1 Immobilization techniques and carrier materials used on bioencapsulation of microbial inoculant to increase plants performance

\begin{tabular}{lllll}
\hline Plant & Technique & Formulation material & Microorganism & Reference \\
\hline Soybean & Gelation & Polyacrylamide & Rhizobium japonicum & Dommergues et al. (1979) \\
Wheat & Cross-linking & Alginate and skim milk & Azospirillum brasilense & Bashan (1986) \\
Wheat & Cross-linking & Alginate, skim milk, and clay & Pseudomonas fluorescens & van Elsas et al. (1992) \\
Onion & Cross-linking & Agar & Enterobacter sp. & Vassilev et al. (1997) \\
Wheat & Cross-linking & Alginate and skim milk & A. brasilense and P. fluorescens & Bashan and Gonzalez (1999) \\
Lettuce & Cross-linking & Alginate and skim milk & Enterobacter sp. & Vassileva et al. (1999) \\
Sugar beet & Cross-linking & Alginate & P. fluorescens & Russo et al. (2001) \\
Tomato & Cross-linking & Alginate, starch, and talc & Streptomyces sp. & Sabaratnam and Traquai (2002) \\
Cattle pasture & Cross-linking & Alginate and wheat bran & Beauveria bassiana & Bextine and Thorvilson (2002) \\
Lettuce & Cross-linking & Alginate and humic acid & Bacillus subtilis & Young et al. (2006) \\
Tomato & Cross-linking & Alginate & A. brasilense and Chlorella sorokiniana & Yabur et al. (2007) \\
Lettuce & Cross-linking & Alginate and humic acid & Pseudomonas putida and B. subtilis & Rekha et al. (2007) \\
Wheat & Cross-linking & Alginate & B. subtilis and Pseudomonas corrugata & Trivedi and Pandey (2008) \\
Legume trees & Cross-linking & Alginate & A. brasilense and Bacillus pumilus & Bashan et al. (2009) \\
Alfalfa & Emulsion & Canola oil and xanthan gum & Sinorhizobium meliloti & John et al. (2010) \\
Cotton seed & Cross-linking & Alginate & Klebsiella oxytoca & Wu et al. (2011) \\
Sorghum & Cross-linking & Alginate & A. brasilense and C. sorokiniana & Trejo et al. (2012) \\
\hline
\end{tabular}

frequently used as protective materials to cells, although they usually turn out to be more expensive.

Carbohydrates such as starches, maltodextrins, corn syrup solid, acacia gums, and so on are used extensively in spray-dried encapsulations (Reineccius 1991). Among the properties of these materials, their low viscosity at high solids contents and good solubility, which are desirable in an encapsulation agent is pointed out.

Starch and products derived from it such as maltodextrins and $\beta$-cyclodextrins have been widely used to encapsulate other type of compounds, such as flavors, being the subject of extensive studies (Reineccius 1991; Goubet et al. 1998; López et al. 2012). Sodium alginate is one of the most commonly used products for the bioencapsulation of microorganisms. The resulting inoculum is used for various purposes: the immobilization of bacteria (Bashan 1986; Bashan et al. 2002), fermentation and application of biological control agents (Bashan and Holguin 1994), or biostimulants for plant growth (Bashan and Levanony 1990; Schoebitz et al. 2012).

Sodium alginate is produced by brown algae, such as Macrocystis pyrifera, Laminaria digitata, Laminaria hyperborean, and Eklonia cava. Alginate production is not exclusive to seaweed. Indeed, there are some bacteria able to produce extracellular alginate. An example is Azotobacter vinelandii (Nunez et al. 2000) and several Pseudomonas strains (Fett et al. 1986, 1989).

Alginates are linear macromolecules comprising two monomers linked by alpha $1-4$ : $\beta$-acid and D-mannuronic acid to $\alpha$-L-guluronic acid having a molecular weight between 20,000 and $200,000 \mathrm{Da}$. The properties of alginate are variable according to the origin of the seaweed and the manufacturing process. For instance, in relation to their molecular weight, alginates will have different solubility properties and complexation with calcium. The alginate solution is mixed with the cell culture and is extruded into a solution of $\mathrm{CaCl}_{2}$ in concentrations from 0.05 to $0.1 \mathrm{M}$. The residence time of the ball in this solution for the complete gelation is around 20 30 min (Cassidy et al. 1996; Fig. 2).

\subsection{Survival of rhizobacteria encapsulated in alginate}

The alginate matrix protects cells from mechanical stress and limits their mortality during prolonged storage (Young et al. 2006). After 1 year of storage at room temperature, the survival rate of Azospirillum lipoferum immobilized in alginate beads dry was $10^{10} \mathrm{CFU} \mathrm{g}^{-1}$. The concentration in this situation was higher than the conventional microbial inoculants (Fages 1992; Trejo et al. 2012).

After 3 years on storage conditions at $4{ }^{\circ} \mathrm{C}$, the survival rate of $B$. subtilis and Pseudomonas corrugata immobilized in sodium alginate beads was $10^{8} \mathrm{CFU} \mathrm{g} \mathrm{g}^{-1}$. Furthermore, both rhizobacteria did not lose their ability to increase the plant growth (Trivedi and Pandey 2008). The survival of strain Azospirillum brasilense $\mathrm{Cd}$ and P. fluorescens 313 immobilized in alginate beads after 14 years on storage conditions was $10^{5}-10^{6} \mathrm{CFU} \mathrm{g}^{-1}$. After this long period of storage, rhizobacteria did not lose their ability to stimulate growth of wheat plants. This research showed that rhizobacteria could survive in the alginate inoculant over long periods (Bashan and Gonzalez 1999). 


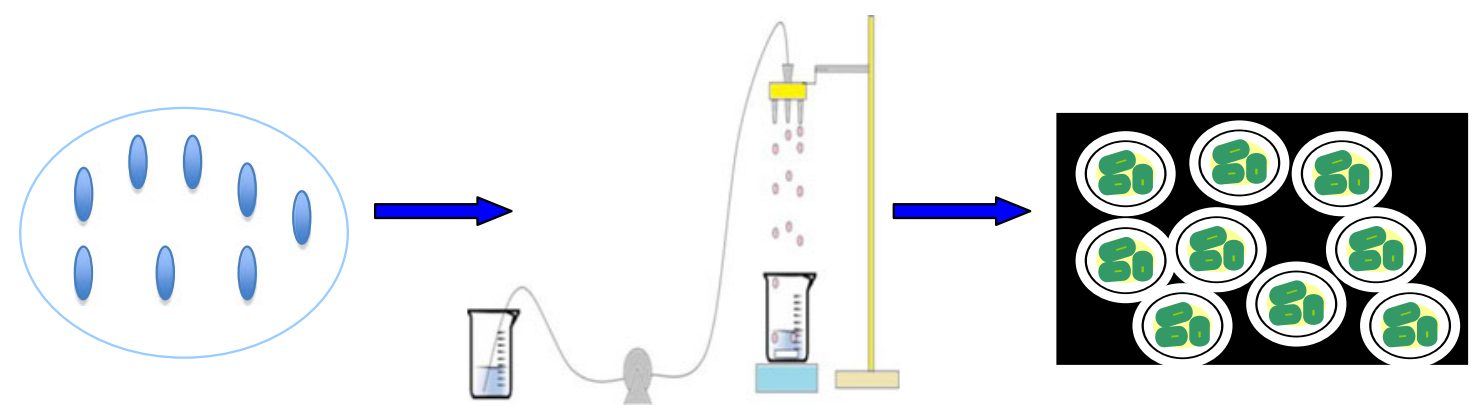

Free bacterial cells

Experimental setup

Bacterial cells into alginate capsules

Fig. 2 Schematic diagrams of encapsulated bacterial cells and making a protective shell around the microorganisms

\subsection{Starch filler in alginate beads}

Calcium alginate beads are structured as a loose network filled with a large quantity of water (Nussinovitch 2010). Thus, using alginate alone for cell bioencapsulation would not adequately protect cells during the drying process and results in slightly distorted beads. Filler materials, such as starch, may be added to the formulation to increase the dry matter in the beads, improving mechanical resistance and allowing for a progressive release of cells into the soil (Bashan et al. 2002). The matrix failed to protect cells during drying as a two log decrease in A. brasilense cell number, due to alginate beads contained around $97-98 \%$ of water (Bashan 1986). Using starch in the bioencapsulation, the water content was reduced to $65 \%$ and significantly improved cell survival (Schoebitz et al. 2012). In addition, it is necessary to take into account that starch is an inexpensive material for bioencapsulation purposes and it is one of the most abundant natural biopolymers (Hickman 1999). It is used as additives and adhesives (John et al. 2011) and also as a filler and carbon source (Tal et al. 1999; Schoebitz et al. 2012). Previous studies on probiotic carriers have revealed a protective effect of starch due to cell adhesion to granules (Wang et al. 1999; O'Riordan et al. 2001a, 2001b). Besides slowing the drying rate, the ability of granular starch to protect the rhizobacteria from drying stress may be due to cell adhesion to this matrix. This hypothesis is supported by microscopic observations of bead sections showing bacteria at the surface of the starch granules (Schoebitz et al. 2012; Fig. 3).

\section{Bioencapsulation techniques}

Different methods are used to encapsulate bacterial cells, pointing out physical processes, such as spray drying, spray chilling/cooling, extrusion, or fluidized bed; chemical processes like co-crystallization, molecular inclusion, or interfacial polymerization; and also physicochemical processes, such as coacervation, liposomes, and gelation/inverse gelation (Madene et al. 2006; Fig. 4). Table 2 summarizes the main advantages and disadvantages of these methods.

Most of these techniques described in this section have been widely used for probiotics in alimentary industries or medical field; however, they are not often applied for PGPR and therefore should be reconsidered in the agricultural field. Currently, the number of microbial inoculant research projects has been intensified in the agricultural industry, caused mainly by the reduction and restriction of chemical fertilizers (Marra et al. 2012).

The bioencapsulation of microbial inoculants is performed in three stages. The first step involves the incorporation of an active ingredient into a matrix (liquid or solid). The second stage is a mechanical operation that involves making dispersion or spraying a solution onto solid particles under mechanical stirring, and the last step consists of a stabilization by a chemical process of polymerization or by a physical-chemical processes (gelation and coacervation) or physical (evaporation and solidification) on a droplet or pellet formed during the second stage. New techniques of encapsulation continue to emerge for developing formulations and processes to manage the improvement of capsule properties and characteristics.

\subsection{Physical processes}

\subsubsection{Spray drying}

Spray drying is a commercial process which is widely used in large-scale production of microbial formulation, is economical and adaptable, and produces an excellent quality of the product. This method involves the dispersion of the bacterial cells in a carrier material forming an emulsion or dispersion, with homogenization of the liquid followed by atomization and spraying of the mixture into a hot chamber (Watanabe et al. 2002) leading to evaporation of the solvent and consequently the development of microcapsules. 
Fig. 3 Scanning electron microscope pictures of alginatestarch bead: a alginate-starch bead; $\mathbf{b}$ transverse section of a alginate-starch bead; c arrow shows distribution of alginate and starch granules on the surface of dried beads; $\mathbf{d}$ and arrow shows Raoultella terrigena TFi08 immobilized and adhered to the surface of starch granules
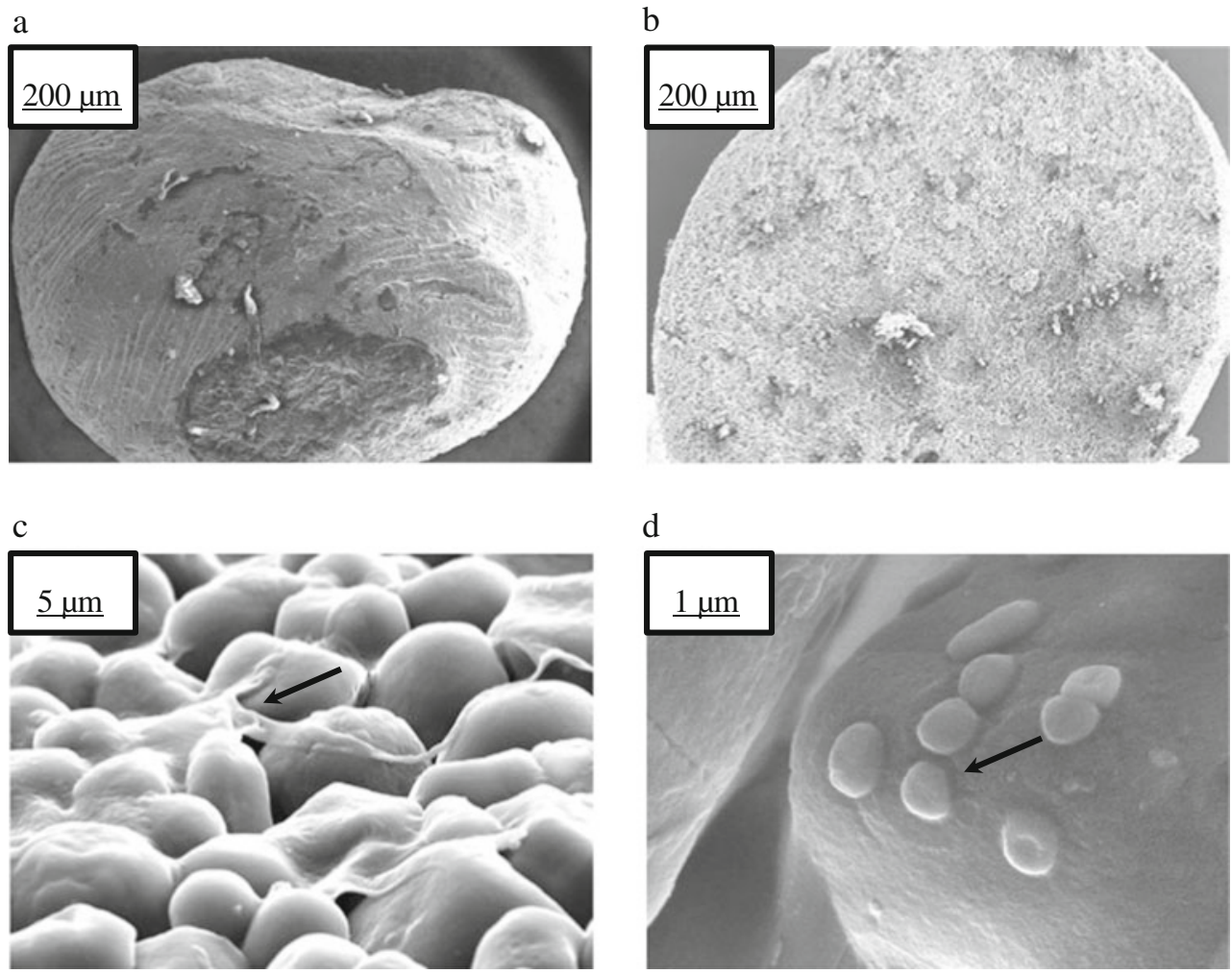

Optimal wall materials for this technique include substances with high solubility in water, low viscosity at high concentration, effective emulsification and filmforming characteristics, and efficient drying properties (Reineccius 1988). The main advantages of the spraydrying process is to manage on a continuous basis, low operating cost, high quality of capsules in good yield, also rapid solubility of the capsules, small size and high stability capsules. However, it is important to take into account some disadvantages of the spray drying, such as the high temperature used in the process which may not be suitable for encapsulating bacterial cultures, the lack of uniformity in the microcapsules produced, or the

a Inclusion complexes

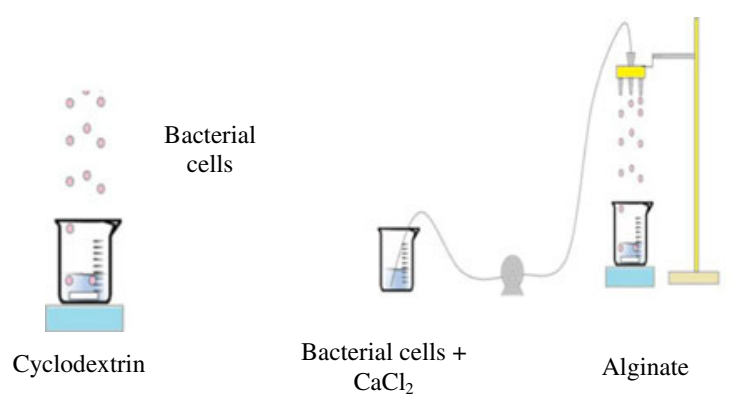

Fig. 4 The schematic diagrams of the experimental set-up corresponding to $\mathbf{a}$ inclusion complexes: cyclodextrins form a cavity in which bacteria are located; $\mathbf{b}$ inverse gelation: bacterial cells and calcium chloride are dropped limitation in the choice of wall material. In addition, this process produces very fine powder that needs further processing and is inadequate for heat-sensitive material (Risch 1995). Nevertheless, appropriate modification and control of the processing conditions (inlet and the outlet temperatures) achieve viable encapsulated cultures of the required particle size distribution.

At an inlet temperature of $100{ }^{\circ} \mathrm{C}$ and low outlet temperature of $45{ }^{\circ} \mathrm{C}$, Bifidobacterium cells were encapsulated satisfactorily to produce microspheres with gelatinized modified starch as a coating material (O'Riordan et al. 2001a). In this study, spray drying was found to be a valuable process for encapsulating these bacteria. c Coacervation

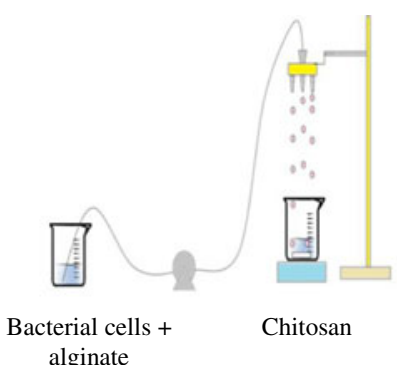

d Oil-Entrapped-Emulsion

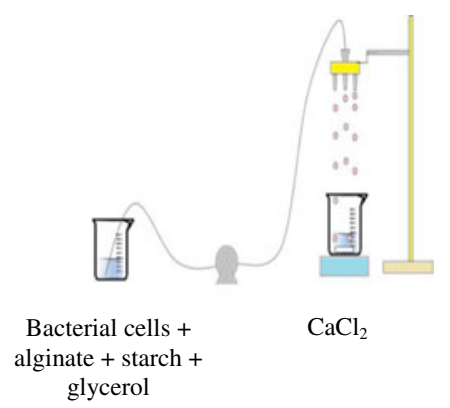

into alginate solution; c coacervation: bacterial cells and alginate form a coacervate with chitosan solution; and $\mathbf{d}$ oil-entrapped emulsion: bacterial cells, alginate, starch, and glycerol are dropped into calcium chloride 


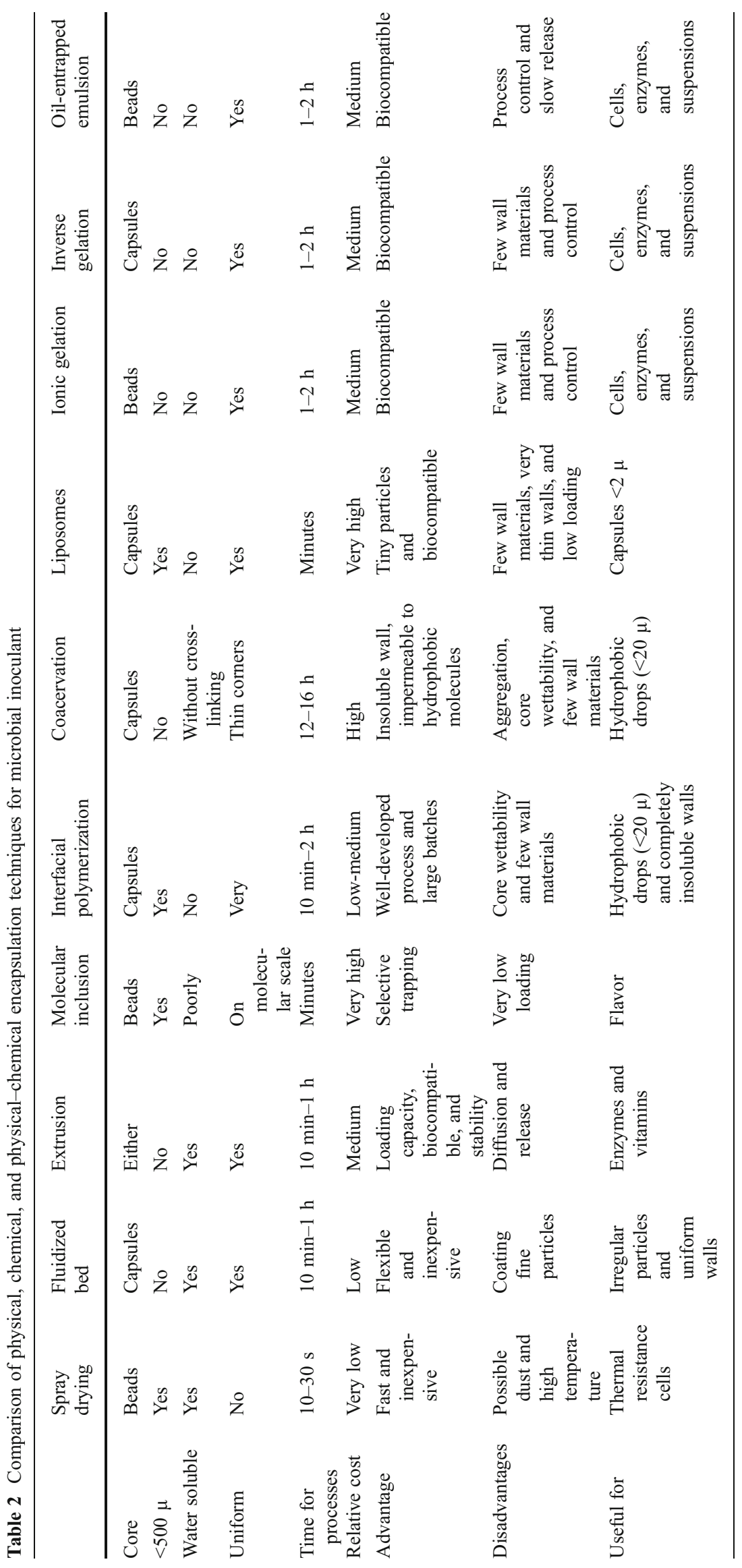


Some reports indicated that survival of bacteria during spray drying decreased with increasing inlet temperature (Mauriello et al. 1999) due to inlet temperatures of above $60{ }^{\circ} \mathrm{C}$ resulting in poor drying and the humid product often accumulated in the cyclone. Other bacterial strains have also been reported to lose viability at higher inlet temperatures (Gardiner et al. 2000; Golowczyc et al. 2010).

On the other hand, other authors (Amiet-Charpentier et al. 1998a, 1999) studied the microencapsulation of the rhizobacteria Pseudomonas fluorescens using the spraydrying technique, focusing on obtaining living bacteria for a minimum of 5 or 6 months, when the inlet temperature was at $60{ }^{\circ} \mathrm{C}$, there was bacterial survival and was estimated around $10^{7} \mathrm{CFU} \mathrm{g}{ }^{-1}$ of powder. From these studies, a relationship between bacteria cells, beads, and residual moisture was observed taking out to be around $25 \%$ of residual moisture as the most excellent conditions.

In spite of this, the spray-drying technology is not considered as a good cell immobilization technique due to a high mortality resulting from simultaneous dehydration and high temperature inactivation of microorganisms like nonspore-forming bacteria (Picot and Lacroix 2003), such as Rhizobium (John et al. 2011). For example, AmietCharpentier et al. (1998a) found $100 \%$ of cells mortality of Pseudomonas strains at the end of the drying process, when the inlet was at a temperature above $80{ }^{\circ} \mathrm{C}$.

\subsubsection{Fluidized bed}

Fluid bed spray coating is a process used to avoid some problems of the spray-drying technique. In this process, the particles to be coated are fluidized with hot air at the coating chamber. After that, the coating material is sprayed through a nozzle onto the particles and film formation is started out, followed by a sequence of wetting and drying stages (Fig. 5). The small droplets of the sprayed liquid reach onto the particles surface and blind them together. The solvent is evaporated by the hot air and the coating material remains on the particles (Jacquot and Pernetti 2003).

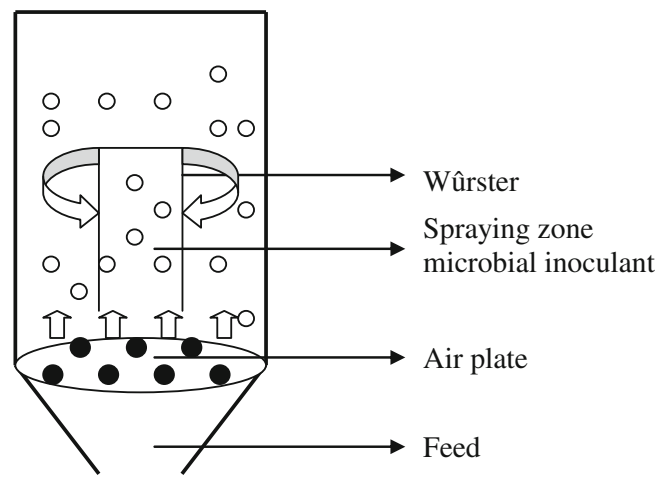

Fig. 5 Fluid bed drying, in this process the particles to be coated are fluidized with hot air at the coating chamber
The advantages of this technology is to allow specific particle size distribution, low porosities (Uhlemann and Mörl 2000), also high drying rates, smaller flow area, high thermal efficiency, lower capital and maintenance costs, and an ease control.

Solid particles extremely tiny to coat properly in a coating pan (particles below $1-2 \mathrm{~mm}$ in diameter) will be coated by fluidizing them and slowly spraying a coating onto the moving fluidized particles. This method works on particles down to $100-150 \mu$, although unusual conditions should be taken into account to avoid aggregation of the fewest quantity of coated particles (Sparks and Jacobs 1999).

Wurster fluid bed device introduced a change of this method by using an open cylinder, which is hanging above the fluidization plate and where the fluidization air fed goes to the center region of the fluidization plate, carrying the particles upward through the cylinder. The particles are not fluidized in this region but are simply being sent out while they desiccate. This deviation gives superior control of the recirculation action of the particles (Prata et al. 2012; Fig. 5).

Fluidized-bed drying is generally considered less stressful for drying cells than spray-drying technology; it involves less extreme water loss and temperature gradients (Larena et al. 2003; Morgan et al. 2006). In spite of being this technique more advantageous, the application of fluidized-bed technology for coating some inoculants is not common. Herridge and Roughley (1974) compared seed pelleted using a fluidized bed with the conventional rotating drum technique and observed that fluidized bed produced a firm pellet, but the survival of the inoculum was low, possibly due to the air temperature occasionally reaching $35^{\circ} \mathrm{C}$. For this reason, the conditions required to obtain capsules of high integrity may compromise viability of the microbial inoculant (Deaker et al. 2004).

\subsubsection{Extrusion}

The microencapsulation by extrusion involves the change of an emulsion of the active material and wall material under high pressure. The bacterial cells are dispersed in a matrix polymer at high temperature (around $110{ }^{\circ} \mathrm{C}$ ). The main advantage of the extrusion method is the stability against oxidation since carbohydrate matrices in the glassy state have excellent barrier properties and consequently extrusion turns out to be a convenient process even though it has very low loading (Gouin 2004). On the other hand, process parameters and diffusion of cells from extruded carbohydrates is enhanced by structural defects such as crakes, thin wall, or pores formed during or after processing (Wampler 1992).

Production of beads can either be accomplished by multinozzle system, rotating disc atomizers, or by the jet-cutting 
technique. Centrifugal system using either a multi-nozzle system or a rotatory disc has also been developed for the mass production of microcapsules (Heinzen 2002).

The centrifugal extrusion technique represents a liquid coextrusion process utilizing a nozzle consisting of concentric orifices located on the outer circumferences of a rotating cylinder (Schalmeus 1995). This liquid or core material is pumped through the inner orifice and a liquid shell material through the outer orifice creating a co-extruded rod of core material delimited by shell material. As the system rotates, the extruded rod breaks up into droplets to form capsules.

\subsection{Chemical processes}

\subsubsection{Molecular inclusion}

The inclusion complexes are defined as the result of interactions between compounds where a smaller guest molecule suits into the lattice formed by the other (Godshall 1997). The main example of molecular inclusion is cyclodextrins, which are enzymatically modified starch molecules (Fig. 6). The inner hydrophobic cavity of $\beta$ cyclodextrin and its molecular dimensions allow total or partial inclusion of a wide range of compounds. The central cavity of the molecule is quite hydrophobic, whereas its external surface has a hydrophilic character. This conformation is basically responsible for the physicochemical properties of cyclodextrins (Shieh and Hedges 1996).

According to Goubet et al. (1998), the retention can be influenced by the molecular weight and shape, steric hindrance, chemical functionality, polarity, and volatility of the core material. The presence of water or high temperature is required to release guest molecules once complexed (Reineccius et al. 2002). On the other hand, the main disadvantages are that cyclodextrins are relatively expensive;

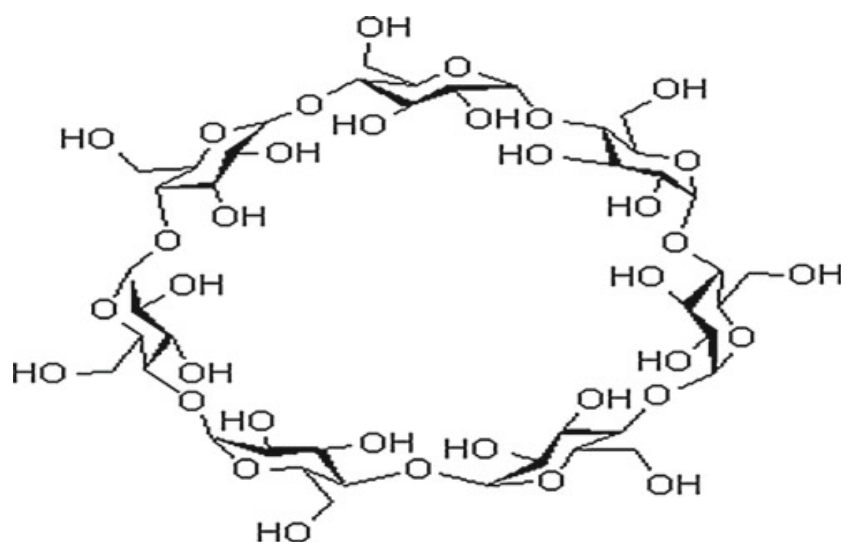

\section{$\beta$-Cyclodextrin}

Fig. 6 Matrix used for molecular inclusion, the inner hydrophobic cavity of $\beta$-cyclodextrin, and its molecular dimensions allow total or partial inclusion of a wide range of compounds
Gouin (2004) suggested that the cost of cyclodextrins would never be lower than $\$ 6 / \mathrm{kg}$, and they present a very low loading. Besides, the immobilization of bacteria could turn out to be complicated due to a size effect. Even though studies about rhizobacteria in inclusion complexes are not often, it is used in the medical field and it could be a promising method (Huang et al. 1999).

\subsubsection{Interfacial polymerization}

Interfacial polymerization technique involves the formation of an emulsion with an aqueous suspension of the cells as the discontinuous phase and an organic solvent as the continuous phase. The droplet containing the cells and the reaction is set off when a biocompatible reagent, soluble in the continuous organic phase, is added to the emulsion. This process allows obtaining a high active loading (up to $90 \%$ ) but involves high $\mathrm{pH}$ and toxic chemicals such as sebacoyl chloride (Yeo et al. 2001). For instance, microcapsules can be produced by dripping an alginate suspension (polyanion) in a chitosan solution (polycation), where the blend of alginate and cells is dripped in a solution of chitosan (acetic acid $1 \%$ at $\mathrm{pH} 4$ ) with continuous stirring.

Synthetic polymers such as nylon or cross-linked polyethyleneimine membranes are unsuitable for live cell immobilization (Larisch et al. 1994) due to the toxicity of the reagents involved in the process. Rao et al. (1989) reported a microencapsulating procedure for Bifidobacterium pseudolongum which involved mixing the bacterial cells with starch and suspending the powder in light paraffin oil.

Chitosan, a water-soluble polymer $(\mathrm{pH}<6)$ has been used to microencapsulate Lactococcus lactis (Groboillot et al. 1993). In this study, a cross-linked chitosan membrane was formed by emulsification/interfacial polymerization using biocompatible reagents with oil-soluble cross-linking agents at low concentrations to minimize cell contact. Nevertheless, the anti-bacterial property of chitosan can limit its use as coating material in encapsulation (Sudarshan et al. 1992; Kong et al. 2010).

L. lactis cells were encapsulated within gelatin membrane cross-linked with toluene-2,4-diisocyanate at an oil/water interface. Reagent toxicity was avoided by the use of vegetable or silicone oil as a dispersant, and by minimizing cell exposure to the water-insoluble cross-linking agent during membrane formation (Hyndman et al. 1993). Larisch et al. (1994) observed a toxic effect mediated by solvents and reagents when L. lactis subspp. Cremoris was encapsulated within poly-L-lysine (PLL) membranes formed on alginate microspheres.

Some studies using monomers that are nontoxic for the microorganisms have been carried out in order to increase their productivity in fermentations with relative success (Groboillot et al. 1994; Hyndman et al. 1993). 


\subsection{Physicochemical processes}

\subsubsection{Coacervation}

Coacervation is a phenomenon of forming a liquid rich in polymer phase in equilibrium with another liquid phase called coacervate (Korus 2001). Generally, the core material used in the coacervation must be compatible with the polymer and has to be insoluble in the coacervation medium. A core material is dispersed in an aqueous solution of one or more polymers; whereas in the aqueous phase, it can change $\mathrm{pH}$, ionic strength, and temperature to induce the formation of a second polymer that becomes the wall material. Coacervation can be simple or complex. Simple coacervation is the result of the interaction of a dissolved polymer with a low molecular substance (for example, gelatin with alcohol or sodium sulfate). Complex coacervation occurs through the interaction of two polymers whose macromolecules bear opposite charges and is achieved by lowering the $\mathrm{pH}$ of a solution containing two polymers, one of which increases positive charges as a result of the change (highisoelectric-point gelatin), and the other one has only negative charges (e.g., Arabic gum) (Bungenberg de Jong 1949).

Optimization of wall material concentration in the emulsification and coacervation process is difficult because the concentration required to obtain a fine emulsion may be different to the concentration needed to increase the yield of microcapsules (Nakagawa et al. 2004). Other limitations are evaporation, dissolution of active compound into the processing solvent, and oxidation of product (Flores et al. 1992).

Therefore, the coacervation method is efficient but expensive and has important limitations. Amiet-Charpentier et al. (1998b) showed that it is possible to obtain a polymercontaining rhizobacteria by complex coacervation.

\subsubsection{Liposomes}

Liposomes are microcapsules-like structures where the coating or outer membrane consists of one or more hydrated bilayers surrounding or encapsulating an active material in the internal compartment (Immordino et al. 2006; Fig. 7). For example, phospholipids may be used to form a spherical bilayer surrounding a nonpolar substance, such as a steroid. Currently, this process is expensive and low loading therefore must be considered only at laboratory scale.

\subsubsection{Ionic gelation}

A drop of aqueous solution or suspension containing the active material and sodium alginate is dropped into a solution of calcium chloride to form the capsules (Lim and Sun 1980). When the drop reaches the calcium chloride solution, a membrane of calcium alginate forms instantaneously,

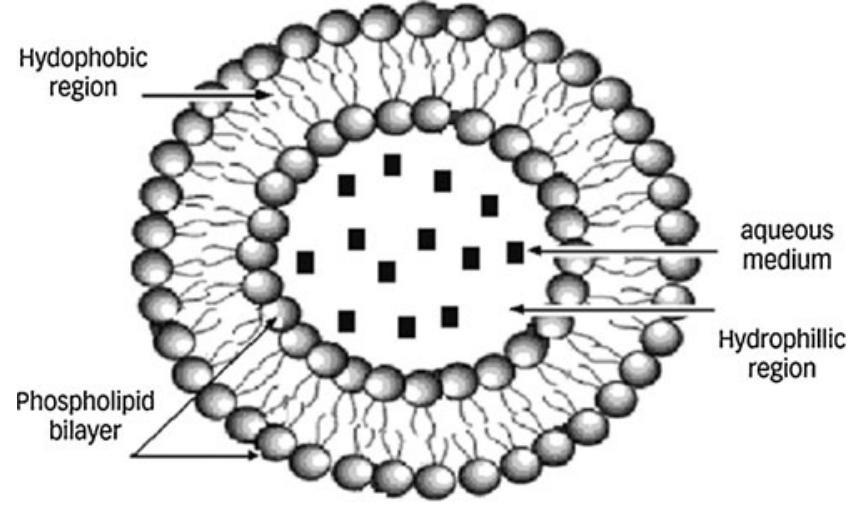

Fig. 7 Liposome structure where the coating or outer membrane consists of one or more hydrated bilayers encapsulating compounds in the internal compartment

maintaining the drop shape in this aqueous/aqueous system. Calcium diffuses in gelling the entire drop, which is then placed in a solution of a polycation that displaces the calcium from the outer surface, forming a permanent membrane. This capsule is then placed in sodium citrate, which slowly solubilizes the calcium through formation of the soluble citrate complex, ungelling the internal portion of the drop. By controlling the molecular weights of the reactants and the times of the reaction, the thickness and size of the permanent wall can be controlled over a wide range.

The conventional method produces calcium alginate beads through ionic gelation by dropping an alginate solution into a calcium chloride solution. The main advantage of gel immobilization is the biocompatibility, although scaling up is difficult and the beads are often porous to cells (Lacroix et al. 1990). Nevertheless, Covarrubias et al. (2012) recently have shown that alginate beads keep some cells inside the beads and prevent outside microbes from entering inside the beads, even under extreme conditions. Roy et al. (1987) presented alginate- containing lactic acid bacteria, which tended to be liquefied by lactic acid. To reduce mass transfer effects, PLL membrane coating of alginate beads followed by liquefaction of the alginate core was reported (Lim 1983); however, leakage of cultures from the matrix was still observed with PLL-alginate beads (Champagne et al. 1992). A variation of this method is to add other materials, such as starch to improve this process to encapsulate rhizobacteria, as is described by Schoebitz et al. (2012) where the matrix solution is prepared by mixing alginate and starch to improve the survival of rhizobacteria species by encapsulating in alginate beads, which allows the stable production of dried beads containing a high cellular concentration.

Sheu and Marshall (1993) reported an emulsion method to encapsulate lactobacilli in calcium alginate gels. In this method, the bacterial cells were mixed with sodium alginate solution and one part of this mixture was added dropwise to 
vegetable oil containing an emulsifier such as Tween 80 . Calcium chloride solution was then added to this emulsion until the water-in-oil-emulsion was broken. Similar procedures were used to encapsulate several kinds of bacteria, such as Bacillus bifidum, Bacillus infantis, and Bacillus longum (Gobbeti et al. 1997; Khalil and Mansour 1998; Kebary et al. 1998).

\subsubsection{Inverse gelation microcapsules by using alginate}

Inverse gelation deals with dropping a calcium suspension in an alginate solution. The conventional method to produce calcium alginate beads through ionic gelation is by dropping an alginate solution into a calcium chloride solution. If the procedure is inversed, that is to say, calcium chloride solution dropped into an alginate solution, aqueous-core calcium alginate capsules are produced (Koyama and Seki 2004; Sasaki et al. 2008). By diffusion in the alginate solution, calcium will gelify the alginate and form a membrane around the droplets. The calcium suspension consists in calcium chloride solution dispersing bacterial cells and this emulsion finally drips into alginate solution (Abang et al. 2012; López et al. 2012). A variation of inverse gelation is performed by using modified starch, which is added in calcium chloride solution, or even starch with alginate solution to increase the solid content in the membrane.

Abang et al. (2012) studied the effects of process variables on the physical properties of capsules produced by the inverse gelation method. In this study, alginate was used to form the capsule membrane and three different methods of incorporating the calcium source in oil were tested. The process variables examined were sodium alginate concentration, calcium chloride concentration, and curing time while physical properties of the capsules investigated were membrane thickness and elastic modulus.

This methodology was used by Jankowski et al. (1997) to develop biocompatible capsules consisting of a liquid core with calcium alginate membranes for encapsulating lactic acid bacteria.

\subsubsection{Beads by oil-entrapped emulsion}

Beads are formed by dripping an alginate solution (containing a dispersion of cells and glycerol) into a calcium solution. Diffusion of the calcium in alginate droplets leads to their gelation (López et al. 2012). Starch and glycerol are added to the formulation to increase the solid content and solve one of the drawbacks of alginate beads, that is to say, decrease porosity since glycerol also increased the viscosity and consequently improved the stability of emulsion.

This method appears to be a promising technology for storing and delivering microorganisms since glycerol could improve both cell viability and controlled release.

\section{Conclusions and future trends}

This review brings information, opening up the potential for succeeding in the encapsulation of microbial inoculants for agricultural purposes, showing the advantages of using them over liquid inoculants, peat, and clay.

The advances in this field have been presented featuring bioencapsulation materials and techniques used for immobilization and bioencapsulation of rhizobacteria. Nevertheless, conventional microbial inoculants are not able to ensure high cell viability during formulation, storage, and inoculated in the soil. Conventional inoculants need to be stored at room temperatures avoiding extreme temperature oscillation, and the shelf life of liquid inoculants on storage conditions is very short and their viability decrease for one or two logs. The use of liquid inoculants is not able to offer protection to rhizobacteria against biotic and abiotic soil stresses, such as $\mathrm{pH}$, moisture, temperature oscillation, and protozoa depredation. Instead, bioencapsulation provides a niche where rhizobacteria are protected from the soil stress. Furthermore, the liquid inoculum, after being introduced into the soil has an instantaneous and very fast release and the rhizobacteria are delivered only in the initial moment of the plant growth. Alternatively, the encapsulated inoculants confer a gradual cells release that achieves long-term fertilizing effects.

Apart from the comparison between capsules and liquid inoculants, one of the most expensive steps is the fermentation since requires to prepare a huge volume of water and broth and sterile medium. However, each capsule into the soil, may act as a mini-bioreactor increasing the concentration of initial viable cells. This can reduce costs associated with the multiplication of bacteria. Furthermore, if there are several capsules around the rhizosphere soil, each capsule may act as an independent unit, which increases the cells concentration enhancing the roots colonization and the microbial inoculants efficacy on the field. The choice of an appropriate technique of bioencapsulation will depend on the properties of the bacteria, the degree of stability required during storage and processing and also the production cost.

Microencapsulation by spray drying is an economical and flexible way to encapsulate bacteria although the temperature used could turn out to be the critical point. In addition, fluidbed process is also becoming a promising encapsulation technique for microbial inoculant large-scale production to be applied in agricultural industry. However, ionic gelation is currently the most adequate method found to encapsulate rhizobacteria. Alginate-starch beads are able to load a high cells concentration at $10^{9} \mathrm{CFU} \mathrm{g}^{-1}$ with an average diameter of bead at more than $4 \mathrm{~mm}$. However, the diameters of beads/capsules have a huge variation of diameter $(1 \mu$ to $6 \mathrm{~mm}$ ) that depend on the encapsulation techniques, bead matrix composition, and the internal diameter of the diffusers. From the farmers and agricultural industry point of view, the 
ideal diameter of the beads should be similar to the seed used. Because, in this way, the process of sowing and the introduction of microbial inoculants can be performed at the same time and using the same seed drill. Additionally, the beads and seeds are introduced close into the soil favoring the effectiveness of the microbial inoculants.

The inconvenience of bioencapsulation technology must not be ignored. Many of the bioencapsulation devices are confectioned to produce beads in laboratory conditions and very small scale. This allows testing encapsulated formulations only in growth chambers and greenhouses conditions. To produce a large amount of inoculant, trials on large fields are required to use innovative bioencapsulation devices. GeniaLab developed the jet cutter technology in Germany. This technology allows the production of beads with a high viscosity involving the fluid transfer through a needle. It is cut into segments evenly with the use of a rotating cutting wheel. The diameter of the beads is conditioned by the speed of rotation of the cutting wheel and the mass of fluid passing through the cutting wheel. Using the jet cutter technology, it is possible to scale-up the production of beads to expand the use of encapsulated microbial inoculants in agriculture. In the future, the developments of new formulation procedures will be determined by the demand of the industry translating the studies from laboratory scale to industrial production.

Acknowledgements One of the authors, MS, would like to thank the National Commission for Scientific and Technological Research of Chile (CONICYT) for the postdoctoral fellowship and Plan Nacional Spain (Project number AGL2009-12530-C02-01).

Declaration of interest The authors inform that there are no conflicts of interest and the authors are the only ones responsible for the content and writing of the paper.

\section{References}

Abang S, Chan ES, Poncelet D (2012) Effects of process variables on the encapsulation of oil in Ca-alginate capsules using an inverse gelation technique. J Microencapsul 29:417-428

Albareda M, Rodríguez-Navarro DN, Camacho M, Temprano FJ (2008) Alternatives to peat as a carrier for rhizobia inoculants: solid and liquid formulations. Soil Biol Biochem 40:2771-2779

Amiet-Charpentier C, Gadille P, Digat B, Benoit JP (1998a) Microencapsulation of rhizobacteria by spray-drying: formulation and survival studies. J Microencapsul 15:639-659

Amiet-Charpentier C, Benoit JP, Gadille P, Richard J (1998b) Preparation of rhizobacteria-containing polymer microparticles using a complex coacervation method. Colloid Surface 144:179-190

Amiet-Charpentier C, Gadille P, Benoit JP (1999) Rhizobacteria microencapsulation: properties of microparticles obtained by spraydrying. J Microencapsul 16:215-229

Bashan Y (1986) Alginate beads as synthetic inoculant carriers for slow release of bacteria that affect plant growth. Appl Environ Microbiol 51:1089-1098
Bashan Y, Levanony H (1990) Current status of Azospirillum inoculation technology: Azospirillum as a challenge for agriculture. Can J Microbiolog 36:591-608

Bashan Y, Holguin G (1994) Root-to-root travel of the beneficial bacterium Azospirillum brasilense. Appl Environ Microbiol 60:2120-2131

Bashan Y (1998) Inoculants of plant growth-promoting bacteria for use in agriculture. Biotechnol Adv 16:729-770

Bashan Y, Gonzalez LE (1999) Long-term survival of the plant-growthpromoting bacteria Azospirillum brasilense and Pseudomonas fluorescens in dry alginate inoculant. Appl Microbiol Biotechnol 51:262-266

Bashan Y, Hernandez JP, Leyva LA, Bacilio M (2002) Alginate microbeads as inoculant carriers for plant growth-promoting bacteria. Biol Fertil Soils 35:359-368

Bashan Y, Holguin G, de-Bashan LE (2004) Azospirillum-plant relationships: physiological, molecular, agricultural, and environmental advances (1997-2003). Can J Microbiol 50:521-577

Bashan Y, de-Bashan LE (2005) Bacteria/plant growth-promotion. In: Hillel D (ed) Encyclopedia of soils in the environment. Elsevier, Oxford, pp 103-115

Bashan Y, Salazar B, Puente ME (2009) Responses of native legume desert trees used for reforestation in the Sonoran Desert to plant growth-promoting microorganisms in screen house. Biol Fertile Soils 45:655-662

Bextine BR, Thorvilson HG (2002) Field applications of baitformulated Beauveria bassiana alginate pellets for biological control of the red imported fire ant (Hymenoptera: Formicidae). Environ Entomol 31:746-752

Bungenberg de Jong HG (1949) Morphology of coacervates. In: Kruyt HR (ed) Colloid science. Elsevier, Amsterdam, pp 335-432

Cassidy MB, Lee H, Trevors JT (1996) Environmental applications of immobilized microbial cells: a review. J Ind Microbiol 16:79-101

Champagne CP, Gaudy C, Poncelet D, Neufeld RJ (1992) Lactococcus lactis release from calcium alginate beads. Appl Environ Microbiol 58:1429-1434

Covarrubias SA, de-Bashan LE, Moreno M, Bashan Y (2012) Alginate beads provide a beneficial physical barrier against native microorganisms in wastewater treated with immobilized bacteria and microalgae. Appl Microbiol Biotechnol 93(6):2669-2680

Deaker R, Roughley RJ, Kennedy IR (2004) Legume seed inoculation technology - a review. Soil Biol Biochem 36:1275-1288

Denton MD, Pearce DJ, Ballard RA, Hannah MC, Mutch LA, Norng S et al (2009) A multi-site field evaluation of granular inoculants for legume nodulation. Soil Biol Biochem 41:2508-2516

Diaz-Zorita M, Fernandez-Canigia MV (2009) Field performance of a liquid formulation of Azospirillum brasilense on dryland wheat productivity. Eur J Soil Biol 45:3-11

Dobbelaere S, Croonenborghs A, Thys A, Ptacek D, Vanderleyden J, Dutto P et al (2001) Responses of agronomically important crops to inoculation with Azospirillum. Aust J Plant Physiol 28:871-879

Dommergues YR, Diem HG, Divies C (1979) Polyacrylamideentrapped Rhizobium as an inoculant for legumes. Appl Environ Microbiol 37:779-781

Fages J (1992) An industrial view of Azospirillum inoculants: formulation and application technology. Symbiosis 13:15-26

Fallik E, Okon Y (1996) Inoculants of Azospirillum brasilense: biomass production, survival and growth promotion of Setaria italica and Zea mays. Soil Biol Biochem 28:123-126

Fett WF, Osman SF, Fishman ML, Siebles TS (1986) Alginate production by plant-pathogenic pseudomonads. Appl Environ Microbiol 52:466-473

Fett WF, Osman SF, Dunn MF (1989) Characterization of exopolysaccharides produced by plant-associated fluorescent pseudomonads. Appl Environ Microbiol 55:579-583 
Flores RJ, Wall MD, Carnahan DW, Orofino TA (1992) An investigation of internal phase losses during the microencapsulation of fragrances. J Microencapsul 3:287-307

Fuentes-Ramirez LE, Caballero-Mellado J (2005) Bacterial biofertilizers. In: Siddiqui ZA (ed) PGPR: Biocontrol and biofertilization. Springer, Dordrecht, pp 143-172

Gardiner GE, O’Sullivan E, Kelly J, Auty MA, Fitzgerald GF, Collins JK et al (2000) Comparative survival rates of human-derived probiotic Lactobacillus paracasei and L. salivarius strains during heat treatment and spray drying. Appl Environ Microbiol 66:2605-2612

Gobbeti M, Corsetti A, Smacchi E, Zocchetti A, De Angleis M (1997) Production of crescenza cheese by incorporation of bifidobacteria. J Dairy Sci 81:37-47

Godshall MA (1997) How carbohydrates influence food flavor. J Food Tech 51:63-67

Golowczyc MA, Silva J, Abraham AG, De Antoni GL, Teixeira P (2010) Preservation of probiotic strains isolated from kefir by spray drying. Lett Appl Microbiol 50:7-12

Goss GR, Baldwin HM, Riepl RG (2003) Clays as biological carriers. In: Downer RA, Mueninghoff JC, Volgas GC (eds) Pesticide formulations and delivery systems: meeting the challenges of the current crop protection industry. American Society for Testing and Materials, Dallas, pp 24-34

Goubet I, Le Quere JL, Voilley A (1998) Retention of aroma compounds by carbohydrate: influence of their physicochemical characteristics and of their physical state. J Agr Food Chem 48:19811990

Gouin S (2004) Microencapsulation: industrial appraisal of existing technologies and trends. Trends Food Sci Tech 15:330-347

Groboillot AF, Champagne CP, Darling GD, Poncelet D, Neufeld RJ (1993) Membrane formation by interfacial cross-linking of chitosan for microencapsulation of Lactococcus lactis. Biotechnol Bioeng 42:1157-1163

Groboillot A, Boadi DK, Poncelet D, Neufeld RJ (1994) Immobilization of cells for application in the food industry. Crit Rev Biotechnol 14:75-107

Haggag WM, Singer S (2012) Development and production of formulations of PGPR cells for control of leather fruit rot disease of strawberry. American Journal of Scientific Research 67:16-22

Heijnen CE, Van Veen JA (1991) A determination of protective microhabitats for bacteria introduced into soil. FEMS Microbiol Ecol 85:73-80

Heijnen CE, Hok-A-Hin CH, Van Veen JA (1992) Improvements to the use of bentonite clay as a protective agent, increasing survival levels of bacteria introduced into soil. Soil Biol Biochem 24:533-538

Heinzen C (2002) Microencapsulation solve time dependent problems for foodmarkers. Eur Food Drink Rev 3:27-30

Herridge DF, Roughley RJ (1974) Survival of some slow-growing Rhizobium on inoculated legume seed. Plant Soil 40:441-444

Hickman MV (1999) Controlled-release pesticide formulations from cornstarch. In: Scher HB (ed) Controlled-release delivery systems for pesticides. Marcel Dekker, New York, pp 153-171

Huang L, Taylor H, Gerber M, Orndorff PE, Horton JR, Tonelli A (1999) Formation of antibiotic, biodegradable, bioabsorbable polymers by processing with neomycin sulphate and its inclusion compound with $\beta$-cyclodextrin. J Appl Polym Sci 74:937-947

Hyndman CL, Groboillot A, Poncelet D, Champagne C, Neufeld RJ (1993) Microencapsulation of Lactococcus lactis with cross-link gelatin membranes. J Chemical Technol Biotechnol 56:259-263

Immordino ML, Dosio F, Cattel L (2006) Stealth liposomes: review of the basic science, rationale, and clinical applications, existing and potential. Int J Nanomedicine 1:297-315

Jacquot M, Pernetti M (2003) Spray coating and drying processes. In: Nedovic V, Willaert R (eds) Cell immobilization biotechnology. Kluwer, Dordrecht, pp 343-356
Jankowski T, Zielinska M, Wysakowska A (1997) Encapsulation of lactic acid bacteria with alginate/starch capsules. Biotechnol Tech $11: 31-34$

John RP, Tyagi RD, Brar SK, Prévost D (2010) Development of emulsion from rhizobial fermented starch industry wastewater for application as Medicago sativa seed coat. Eng Life Sci 10:248-256

John RP, Tyagi RD, Brar SK, Surampalli RY, Prévost D (2011) Bioencapsulation of microbial cells for targeted agricultural delivery. Crit Rev Biotechnol 31:211-226

Kebary KMK, Hussein SA, Basawi RM (1998) Improving viability of bifidobacteria and their effect on frozen milk. Egyptian J Dairy Sci 26:319-337

Khalil AH, Mansour EH (1998) Alginate encapsulated bifidobacteria survival in mayonnaise. J Food Sci 63:702-705

Kim KI, Baek YJ, Yoon YH (1996) Effects of rehydration media and immobilisation in calcium-alginate on the survival of Lactobacillus casei and Bifidobacterium bifidum. Korean J Dairy Sci 18:193-198

Kim IY, Pusey PL, Zhao Y, Korban SS, Choi H, Kim KK (2012) Controlled release of Pantoea agglomerans E325 for biocontrol of fire blight disease of apple. J Control Release 161:09-15

Kloepper J, Schroth MN (1981) Development of a powder formulation of rhizobacteria for inoculation of potato seed pieces. Phytopathology 71:590-592

Kong M, Chen XG, Xing K, Park HJ (2010) Antimicrobial properties of chitosan and mode of action: a state of the art review. Int J Food Microbiol 144(1):51-63

Korus J (2001) Microencapsulation of flavours in starch matrix by coacervation method. Pol J Food Nutr Sci 51:17-23

Koyama K, Seki M (2004) Evaluation of mass-transfer characteristics in alginate-membrane liquid-core capsules prepared using polyethylene glycol. J Biosci Bioeng 98:114-121

Lacroix C, Paquin C, Arnaud JP (1990) Batch fermentation with entrapped growing cells of Lactobacillus casei. Optimisation of the rheological properties of the entrapment gel matrix. Appl Microbiol Biotechnol 32:403-408

Larena I, Melgarejo P, Cal AD (2003) Drying of Conidia of Penicillum oxalicum, a biological control agent against Fusarium wilt of tomato. J Phytopathol 151:600-606

Larisch BC, Poncelet D, Champagne CP, Neufeld RJ (1994) Microencapsulation of Lactococcus lactis subsp. cremoris. J Microencapsul 11:189-195

Lemanceau P (1992) Effets benefiques de rhizobacteries sur les plantes: exemple des Pseudomonas spp fluorescents. Agronomie 12:413-437

Lim F, Sun AM (1980) Microencapsulated islets as bioartificial endocrine pancreas. Science 210:908-910

Lim F (1983) Microencapsules containing viable tissue cells. US Patent 4391909. July 5

López MD, Maudhuit A, Pascual-Villalobos MJ, Poncelet D (2012) Development of formulations to improve the controlled-release of linalool to be applied as an insecticide. J Agric Food Chem 60:1187-1192

Lugtenberg BJJ, Kamilova F (2009) Plant-growth-promoting rhizobacteria. Annu Rev Microbiol 63:541-556

Madene A, Jacquot M, Scher J, Desobry S (2006) Flavour encapsulation and controlled release - a review. Int J Food Sci Tech 41:1-21

Marra LM, Fonseca Sousa Soares CR, Oliveira SM, Avelar Ferreira PA, Soares BL, Fraguas CR et al (2012) Biological nitrogen fixation and phosphate solubilization by bacteria isolated from tropical soils. Plant Soil 357:289-307

Mauriello G, Aponte M, Andolfi R, Moschetti G, Villani F (1999) Spray-drying of bacteriocin-producing lactic acid bacteria. J Food Prot 62:773-777

Morgan CA, Herman N, White PA, Vesey G (2006) Preservation of microorganisms by drying. A review. J Microbiol Meth 66:183193 
Nakagawa K, Iwamoto S, Nakajima M, Shono A, Satoh K (2004) Microchannel emulsification using gelatine and surfactant-free coacervate microencapsulation. J Colloid Interf Sci 278:198-205

Nunez C, Leon R, Guzman J, Espin G, Soberon-Chavez G (2000) Role of Azotobacter vinelandii mucA and mucC gene products in alginate production. J Bacteriol 182:6550-6556

Nussinovitch A (2010) Polymer macro and micro-gel beads: fundamentals and applications. Springer, Berlin, $303 \mathrm{pp}$

O'Riordan K, Andrews D, Buckle K, Conway P (2001a) Evaluation of microencapsulation of a Bifidobacterium strain with starch as an approach to prolonging viability during storage. J Appl Microbiol 91:1059-1066

O'Riordan K, Muljadi N, Conway P (2001b) Characterization of factors affecting attachment of Bifidobacterium species to amylomaize starch granules. J Appl Microbiol 90:749-754

Okon Y, Labandera-Gonzalez CA (1994) Agronomic applications of Azospirillum: an evaluation of 20 years worldwide field inoculation. Soil Biol Biochem 26:1591-1601

Park M, Kim C, Yang J, Lee H, Shin W, Kim S et al (2005) Isolation and characterization of diazotrophic growth promoting bacteria from rhizosphere of agricultural crops of Korea. Microbiol Res 160:127-133

Pedraza RO (2008) Recent advances in nitrogen-fixing acetic acid bacteria. Int J Food Microbiol 125:25-35

Picot A, Lacroix C (2003) Production of multiphase water-insoluble microcapsules for cell microencapsulation using an emulsification/spray-drying technology. J Food Sci 68:2693-2700

Prata AS, Maudhuit A, Boillereaux L, Poncelet D (2012) Development of a control system to anticipate agglomeration in fluidised bed coating. Powder Technol 224:168-174

Rao AV, Shiwnarain N, Maharaj I (1989) Survival of microencapsulated Bifidobacterium pseudolongum in simulated gastric and intestinal juices. Can Inst Food Sci Technol J 22:345-349

Reineccius G (1988) Spray-drying of food flavours. In: Risch SJ, Reineccius GA (eds) Flavor encapsulation. American Chemical Society, Washington, pp 55-66

Reineccius G (1991) Off-flavors in foods. Crit Rev Food Sci Nutr 29:381-402

Reineccius TA, Reineccius GA, Peppard TL (2002) Encapsulation of flavors using cyclodextrins: comparison of flavor retention in alpha, beta and gamma types. J Food Sci 67:3271-3279

Rekha PD, Lai WA, Arun AB, Young CC (2007) Effect of free and encapsulated Pseudomonas putida CC-FR2-4 and Bacillus subtilis CC-pg104 on plant growth under gnotobiotic conditions. Bioresour Technol 98:447-451

Risch SJ (1995) Encapsulation: overview of uses and techiniques. In: Rish SJ, Reineccius GA (eds) Encapsulation and Controlled Release of Food Ingredient. American Chemical Society, Washington, pp 2-7

Rivera-Cruz MC, Trujillo-Narcía A, Córdova-Ballona G, Kohler J, Caravaca F, Roldán A (2008) Poultry manure and banana waste are effective biofertilizer carriers for promoting plant growth and soil sustainability in banana crops. Soil Biol Biochem 40:3092-3095

Rodriguez H, Fraga R, Gonzalez T, Bashan Y (2006) Genetics of phosphate solubilization and its potential applications for improving plant growth-promoting bacteria. Plant Soil 287:15-21

Rose MT, Deaker R, Potard S, Thi Tran CK, Vu NT, Kennedy IR (2011) The survival of plant growth promoting microorganisms in peat inoculant as measured by selective plate counting and enzyme-linked immunoassay. World J Microbiol Biotechnol 27:1649-1659

Roy D, Goulet J, Le Duy A (1987) Continuous production of lactic acid from whey permeate by free and calcium alginate entrapped Lactobacillus helveticus. J Dairy Sci 70:506-513

Russo A, Basaglia M, Tola E, Casella S (2001) Survival, root colonisation and biocontrol capacities of Pseudomonas fluorescens
F113 LacZY in dry alginate microbeads. J Ind Microbiol Biotechnol 27:337-342

Sabaratnam S, Traquair J (2002) Formulation of a Streptomyces biocontrol agent for the suppression of Rhizoctonia damping-off in tomato transplants. Biol Control 23:245-253

Sasaki E, Kuruyama F, Ida J, Matsuyama T, Yamamoto H (2008) Preparation of microcapsules by electrostatic atomization. J Electrostat 66:312-318

Schalmeus W (1995) Centrifugal extrusion encapsulation. In: Rish SJ, Reineccius GA (eds) Encapsulation and controlled release of food ingredient. American Chemical Society, Washington, pp 96-103

Schoebitz M, Ribaudo C, Pardo M, Cantore M, Ciampi L, Cura JA (2009) Plant growth promoting properties of a strain of Enterobacter ludwigii isolated from Lolium perenne rhizosphere. Soil Biol Biochem 41:1768-1774

Schoebitz M, Simonin H, Poncelet D (2012) Starch filler and osmoprotectants improve the survival of rhizobacteria in dried alginate beads. J Microencapsul 29:532-538

Sheu TY, Marshall RT (1993) Microentrapment of Lactobacilli en calcium alginate gels. J Food Sci 58:557-561

Shieh WJ, Hedges AR (1996) Properties and applications of cyclodextrins. J Macromol Sci 33:673-683

Singleton P, Keyser H, Sande E (2002) Development and evaluation of liquid inoculants. Inoculants and nitrogen fixation of legumes in Vietnam. In: Herridge D (ed) ACIAR Proceedings.

Smith RS (1992) Legume inoculant formulation and application. Can J Microbiol 38:485-492

Smith RS (1997) New inoculant technology to meet changing legume management. In: Elmerich AKC, Newton WE (eds) Biological nitrogen fixation for the 21 st century. Kluwer, Dordrecht, pp 621622

Spaepen S, Vanderleyden J, Remans R (2007) Indole-3-acetic acid in microbial and microorganism-plant signaling. FEMS Microbiol Rev 31:425-448

Sparks RE, Jacobs IC (1999) Selection of coating and microencapsulation processes. In: Scher HB (ed) Controlled-release delivery system for pesticides. Marcel Dekker, New York, pp 3-29

Stephens JHG, Rask HM (2000) Inoculant production and formulation. Field Crop Res 65:249-258

Sudarshan NR, Hoover DG, Knorr D (1992) Antibacterial action of chitosan. Food Biotechnol 6:257-272

Tal Y, van Rijn J, Nussinovitch A (1999) Improvement of mechanical and biological properties of freeze-dried denitrifying alginate beads by using starch as a filler and carbon source. Appl Microbiol Biotechnol 51:773-779

Temprano FJ, Albareda M, Camacho M, Daza A, Santamaria C, Rodriguez-Navarro DN (2002) Survival of several Rhizobium/ Bradyrhizobium strains on different inoculant formulations and inoculated seeds. Int Microbiol 5:81-86

Trejo A, de-Bashan LE, Hartmann A, Hernandez JP, Rothballer M, Schmid M, Bashan Y (2012) Recycling waste debris of immobilized microalgae and plant growth-promoting bacteria from wastewater treatment as a resource to improve fertility of eroded desert soil. Environ Exp Bot 75:65-73

Trevors JT, van Elsas JD, Lee H, van Overbeek LS (1992) Use of alginate and other carriers for encpasulation of microbial cells for use in soil. Microb Releases 1:61-69

Trivedi P, Pandey A (2008) Recovery of plant growth-promoting rhizobacteria from sodium alginate beads after 3 years following storage at 4 degrees C. J Ind Microbiol Biotechnol 35:205-209

Uhlemann J, Mörl L (2000) Wirbelschicht-Sprühgranulation. Springer, New York

van Elsas J, Trevors J, Jain D, Wolters A, Heijnen C, van Overbeek L (1992) Survival of, and root colonization by, alginateencapsulated Pseudomonas-fluorescens cells following introduction into soil. Biol Fert soils 14:14-22 
Vassilev N, Toro M, Vassileva M, Azcon R, Barea JM (1997) Rock phosphate solubilization by immobilized cells of Enterobacter sp. in fermentation and soil conditions. Bioresour Technol 61:29-32

Vassilev N, Vassileva M, Azcon R, Medina A (2001) Application of free and Ca-alginate-entrapped Glomus deserticola and Yarowia lipolytica in a soil-plant system. J Biotechnol 91:237-242

Vassileva M, Azcon R, Barea JM, Vassilev N (1999) Effect of encapsulated cells of Enterobacter sp on plant growth and phosphate uptake. Bioresour Technol 67:229-232

Wampler DJ (1992) Flavor encapsulation: a method for providing maximum stability for dry flavors systems. Cereal foods World $37: 817-820$

Wang X, Brown IL, Evans AJ, Conway PL (1999) The protective effects of high amylose maize (amylomaize) starch granules on the survival of Bifidobacterium spp. in the mouse intestinal tract. J Appl Microbiol 87:631-639

Watanabe Y, Fang X, Minemoto Y, Adachi S, Matsuno R (2002) Suppressive effect of saturated acyl L-ascorbate on the oxidation of linoleic acid encapsulated with maltodextrin or gum arabic by spray-drying. J Agric Food Chem 50:3984-3987
Wu Z, Zhao Y, Kaleem I, Li C (2011) Preparation of calcium-alginate microcapsuled microbial fertilizer coating Klebsiella oxytoca Rs5 and its performance under salinity stress. Eur J Soil Biol 47:152-159

Wu Z, Guo L, Qin S, Li C (2012) Encapsulation of R. planticola Rs-2 from alginate-starch-bentonite and its controlled release and swelling behavior under simulated soil conditions. J Ind Microbiol Biotechnol 39:317-327

Yabur R, Bashan Y, Hernández-Carmona G (2007) Alginate from the macroalgae Sargassum sinicola as a novel source for microbial immobilization material in wastewater treatment and plant growth promotion. J Appl Phycol 19:43-53

Yeo Y, Back N, Park K (2001) Microencapsulation methods for delivery of protein drugs. Biotechnol Bioproc E 6:213-230

Young CC, Rekha PD, Lai WA, Arun AB (2006) Encapsulation of plant growth-promoting bacteria in alginate beads enriched with humic acid. Biotechnol Bioeng 95:76-83

Zaidi A, Khan MS, Ahemad M, Oves M (2009) Plant growth promotion by phosphate solubilizing bacteria. Acta Microbiol Immunol Hung 56:263-284 